\title{
Prospects for the Development of the Event Industry in the Context of the Pandemic
}

\author{
Evgenia Radygina ${ }^{1, *}$, and Alla Oshkordina ${ }^{1}$ \\ Ural State University of Economics, Department of Tourism Business and Hospitality, 620144 \\ Yekaterinburg, Russia
}

\begin{abstract}
The coronavirus pandemic in 2020 had a significant impact on all areas of economic activity. One of the most affected industries was the event industry. The organizers of the events faced external changes that required a radical restructuring of their activities and organizational structures. The analysis showed that most of the problems of the industry noted before the outbreak of the pandemic, and the restrictions imposed only revealed the need for their immediate solution. The article reflects the main measures taken by organizations to ensure anti-epidemic safety during events and when organizing the activities of employees, the most popular anti-crisis measures. The mechanisms taken by organizations are associated with a decrease in demand and the transition to the online space. In addition, there are trends that can influence the development of the event industry and related industries in the long term.
\end{abstract}

\section{Introduction}

The event industry is an independent branch of economic activity that covers the entire range of services for events. The event industry closely interacts with the development of business and event tourism. Events affect the formation of the image of the region, contribute to attracting tourists and generating income from related services (transport, restaurant, tourist, hotel, entertainment, cultural, etc.).

The event industry is a young sphere of the Russian economy, but it is quite promising and highly profitable, creating a multiplicative effect. However, the massive cancellation of major offline events and the introduction of anti-epidemic restrictions led the industry to the need for a radical restructuring of its activities. The situation required the adaptation of the organizational mechanisms of the event organizations.

\section{Materials and methods of research}

The structure of the event industry was considered by D. Ostrovskaya, A. Stuglev, A. Chuvaev, E. Chetyrkina, I. Makushenko, A. Smirnova, A. Yurkova [1], A. Shumovich [2]. The mechanisms of development of event tourism in Russia are reflected in the works of M. Goryainova [3], A. Sadovnichy [4], L. Nyurenberger, I. Sevryukova, N. Petrenko [5].

\footnotetext{
*Corresponding author: radygina@bk.ru
} 
The analysis of factors and identification of problems affecting the development of the event industry, event and congress tourism reflected in the works of Yu. Belousova [6], A. Zemlyannaya, D. Savostin [7].

The research of the economic performance indicators of event organizations was based on data from marketing and empirical studies, official information from regional authorities, surveys, discussions with representatives of the event industry, and in-depth interviews [8], [9], [10].

The event industry involves holding events of both business and non-business nature, related to three segments: exhibition, special events, and industry meetings. Business events include exhibitions, congresses, incentive programs, etc., while non-business events include festivals, holidays, social events, sports events, etc. [1, pp. 8-9].

A. Shumovich and A. Berlov define an event as "a type of human activity involving the meeting and interaction of different people, limited in time and associated with the implementation of any common goals" [2, p.83].

The volume of the event market at the beginning of April 2020 in Russia estimated at 161.1 billion rubles, 2,060 companies were actively working on it, two-thirds of them were small and microenterprises, $69 \%$ were young companies created over the past 5 years [11].

Event events are one of the BTL marketing tools of the enterprise. Below-the-Line events include direct marketing (direct mailing); promotions aimed at the end user; incentives; production and use of special materials; special events. The share of event events in Russia at the beginning of 2020 was $15 \%$ of the market for all BTL services (which was about 13.6 billion rubles) and was developing steadily before the outbreak of the pandemic, with an annual increase planned to reach 24 billion rubles [12].

The tourism industry and the related event industry have been significantly affected by the introduction of coronavirus restrictions. From January to December 2020, 57 major events were planned with the participation of the Government of the Sverdlovsk Region, including 38 in the Sverdlovsk Region (67\%) and 19 outside the Sverdlovsk Region (33\%). $67 \%$ of them were canceled or postponed, including 2 events planned for the territory of the Sverdlovsk region postponed to 2021 (5\%) and 22 events were canceled (58\%). Of the events planned with the participation and support of the Government of the Sverdlovsk Region outside the territory, 4 (3\%) were postponed and $10(53 \%)$ were canceled [9]. Companies found themselves in an environment of uncertainty, and the decline in business contacts put the existence of many campaigns at risk: there were cancellations and postponements of events, job cuts, forced vacations, and business closures. The market volume decreased in financial terms by about $68 \%$ compared to the pre-crisis period, the total losses of the industry exceeded 100 billion rubles [4, p. 402].

Yu. S. Belousova draws attention to the need to create events that are in demand by visitors with the maximum level of involvement, the need for a differentiated approach to better meet the needs of different guests [6, p. 42]. It is also necessary to develop a methodological framework for assessing the impact of the event industry on the volume of tourist traffic to the regions. The innovations will help more targeted preparation of supporting events for industry organizations, but the process complicated by the multifactor impact of the event industry on other sectors of economic activity in the region.

\section{Results of the researches}

The study revealed several types of problems in the event industry:

1) Problems related to the youth of the event industry in Russia:

- imperfection of the regulatory framework of the event industry;

- insufficient use of the existing capabilities of the territory and the material and technical base; 
- lack of a comprehensive approach to the development of the congress infrastructure;

- a formal approach to creating a calendar of events in the regions and insufficient promotion outside the territory;

- weak support for tourist events at the stage of their creation and formation by state authorities;

- lack of specially designed souvenir products for most events.

2) Problems arising from the coronavirus pandemic:

- postponement and cancellation of mass events, reduction of tourist traffic from other regions, loss of profit by event organizations;

- lack of new tourist activities in the regions.

It is worth noting that the occurrence of the overwhelming number of problems is not related to the pandemic, the restrictions have affected their deepening and awareness of the participants of the event industry.

With a decrease in the tourist flow from abroad, associated with the cancellation of events and their transfer to online, the need to attract domestic tourists, reorient the sphere to domestic markets, and promote it in neighboring Russian regions was revealed. It has also become relevant to attract individual groups of consumers, which previously paid little attention. Event budgets and the number of offline participants reduced, so in order to ensure a profit margin, organizers need to hold more events. The market for small events is becoming more competitive.

Over the past period, there has been a significant decrease in the number of full-time participants in relation to the planned one.

When calculating losses from a decrease in event activity, it is necessary to take into account not only the decrease in the income of event organizations, but also destinations and tourist clusters, since the event industry has a multiplier effect in relation to other sectors of the economy that are closely related to the event market. Given this factor, the decline in activity in the event market during the pandemic led to the release of labor and lower wages. According to the data of the Employment Service of the Sverdlovsk region by types of activities in the field of culture, sports, leisure and entertainment in the period from 01.01.2020 to 01.10 .2020 , the average number of employees of organizations decreased by $0.7 \%$ (to 26,627 people), while the number of unemployed increased 3.5 times (to 1,24 people) [1, p. 3-6].

For the organization of mass offline events, a necessary condition is the implementation of anti-epidemic measures: a 50-percent limit on the number of seats, technical equipment of the site, organization of sanitary treatment of the site, the use of protective equipment (masks and gloves), ensuring non-contact interactions of personnel with participants. For each event, it is necessary to assess the epidemiological risks in advance, draw up antiepidemic passports of the objects involved in the event, and plan measures to minimize the risks [11].

The most common measures for the prevention of coronavirus within the framework of the events were: informing participants about personal hygiene measures and preventing the spread of the virus (32\%), placing disinfectants on the site $(23 \%)$, enhanced disinfection/decontamination of the site $(18 \%)$, monitoring the number of people at the event $(14 \%)$, measuring body temperature at the entrance to the event $(6 \%)$, no special measures were taken (7\%) (Fig. 1). 


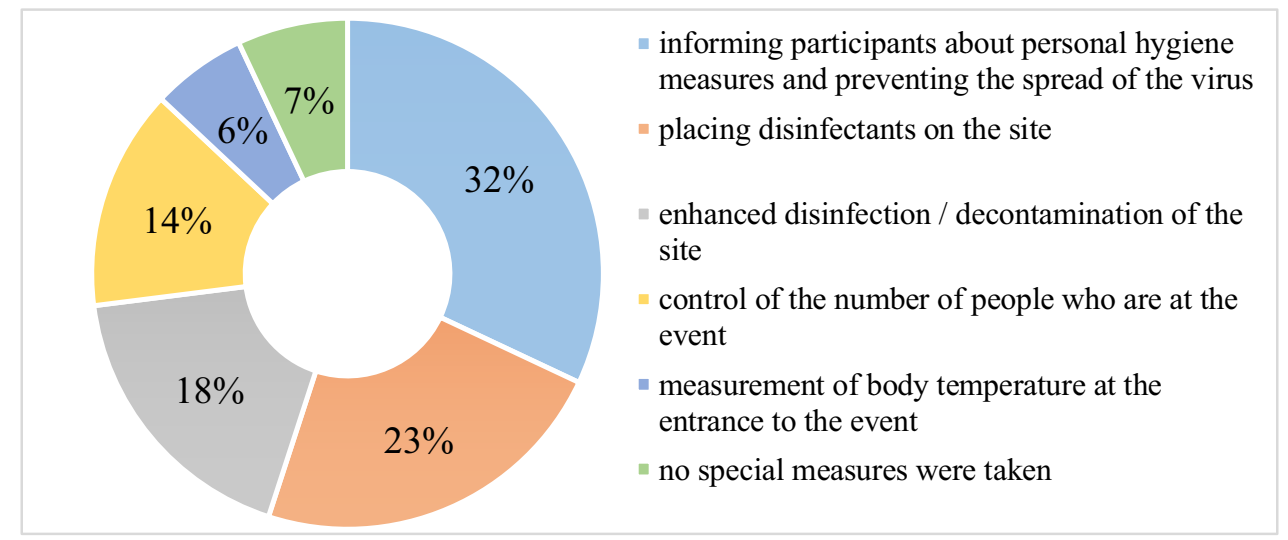

Fig. 1. Measures for the prevention of coronavirus within the framework of the measures taken [8], [9].

Employers have taken a responsible approach to the safety measures of their employees.

The most popular measures to protect employees are as follows:

- informing participants about personal hygiene measures and preventing the spread of the virus $(74 \%)$;

- switching to remote work $(73 \%)$;

- placing disinfectants in the office (56\%);

- cancellation of business trips in Russia and abroad (51\%);

- enhanced disinfection/decontamination of office premises (38\%).

Only $3 \%$ of the organizations did not take any special measures.

In the survey, respondents representing $12 \%$ of the total number of enterprises in the event market indicated that they planned to hold events in 2020, which were to be attended by more than 500,000 foreign guests as exhibitors, visitors, and delegates.

Taking into account the average cost per day of one participant (400-500 US dollars at the pre-crisis rate of 60-70 rubles per 1 dollar) and the average duration of the event (3 days), we can roughly calculate the damage that the Russian economy will suffer from the loss of only foreign participants of canceled events-more than 40 billion rubles.

The analysis of the forecasts made shows that to overcome the crisis situation, the companies participating in the market will first of all optimize the costs of the organization, while trying to preserve the teams. This is due to the fact that the level of professionalism of employees is developed by practice and training within the company. It is very difficult to find a replacement for such specialists. At the same time, the success of the organization of events, and hence the commercial efficiency of the company, largely depends on the level of employees. It is important to note that even if the first scenario is implemented in the market, about $8 \%$ of the companies-respondents consider the possibility of closing the organization and leaving the market.

It becomes relevant to hold events of a hybrid format, combining face-to-face and online forms of organizing events. In this regard, applications for events are becoming popular, including tools for creating an event program and an individual participation plan, geotagging on maps, electronic registration (smart badges), creating photo and video content, organizing networking and communication of participants, collecting and analyzing feedback, etc. Visitors to the events, in turn, are interested in self-planning of participation and organizing operational communication with the organizers on emerging issues. The active use of digital technologies in the event industry makes it possible to 
improve the quality of services, individualize the offer and improve interaction among event participants.

Combining online and offline formats requires serious organizational training:

- better training of the moderator and compliance with the timing associated with the control of a large audience;

- tracking of participants' visits in accordance with the paid tariff;

- working out ways to analyze the involvement of participants;

- setting up multi-channel networking (questions to speakers, chats of participants, chatbots by interests and directions, telegram channels for informal communication, access to the webinar room for personal communication, etc.);

- organization of virtual stands and presentations, setting up gamification tools.

\section{Discussion}

The discussion of the research results took place within the framework of participation in scientific and practical events:

-International Scientific and Practical Conference "COVID-19: Technologies for Studying the Consequences of the spread of the coronavirus pandemic" (RTCOV 2020), October 15-16, 2020, Yekaterinburg, Russia;

- International Congress "Transforming Administrative Management", October 31, 2020, CLAD, Lima, Peru;

- I International Scientific and Practical Conference "Strategic Vectors of Tourism and Hospitality Industry Development: Global, National, Regional dimension", November 25, 2020, Yekaterinburg, Russia.

\section{Conclusion}

Thus, the strategic transformations of the event industry that emerged as a necessity revealed the main directions of the industry's development not only during the pandemic, but also for several years to come. The development of the event industry will allow you to individualize participation in events and make the networking space even more comfortable, use gamification tools to engage participants, quickly analyze and fulfill requests, ensure security, etc.

Among the elements of adaptation of the event industry in the context of the pandemic, we can distinguish:

- reorientation to the domestic market, promotion of services for individual groups;

- active development of online tools for conducting and organizing events;

- optimization of the organizational structure (reduction of staff, transfer of employees to remote work, etc.);

- increased attention to the promotion of territories and event venues, the formation of deferred demand, and the promotion of pre-orders.

Based on the analysis of existing trends, it is possible to predict:

- changes in the processes of organizing and conducting events related to the expansion of contactless service and networking tools;

- complicating the structure of online programs and making them a mandatory part of offline events, further diversifying participation options, including offline, online, and deferred participation options;

- the emergence of software products that combine different events for all participants and visitors; 
- increasing the requirements of participants and visitors to the quality of the organization of events and ensuring an immediate response to comments.

\section{References}

1. Ostrovskaya, A. Stuglev, A. Chuvaev, E. Chetyrkina, I. Makushenko, A. Smirnova, A. Yurkova, ed. K. Zbarovsky, A short dictionary of terms and key concepts of the event industry. The Meeting Industry, p. 148 (2018).

2. A. Shumovich, A. Berlov, Mix, but not shake: Recipes for organizing events, p. 320 (2017).

3. M. Goryainova, Russian Economic Bulletin, 3/1, pp. 168-176 (2020).

4. A. Sadovnichaya Scientific Works of the VEO of Russia, 3, p. 400-405 (2020).

5. L. Nyurenberger, I. Sevryukov, N. Petrenko, Innovations and Investments, 5 (2020).

6. Yu. Belousova, Skif, 5-2 (45) (2020).

7. A. Zemlyannaya, D. Savostin, Economics and Business: Theory and Practice, 7 (2020).

8. Market research "COVID-19: Threats and challenges for the event industry in Russia. Results of the survey of market participants. March-April 2020", p. 38 (2020).

9. On approval of the List of exhibition and Fair and congress events held with the participation and support of the Government of the Sverdlovsk Region for 2020 (as amended on October 30, 2020), p.18 (2020).

10. Draft Resolution On Amendments to the set of measures aimed at restoring the number of employed people in the Sverdlovsk Region (to the level of 2019) by the fourth quarter of 2021, approved by the Decree of the Government of the Sverdlovsk Region of 22.10.2020 No. 768-PP "On Approval of a set of measures aimed at restoring the number of employed people in the Sverdlovsk Region (to the level of 2019) by the fourth quarter of 2021" (2021).

11. Organization of sanitary and anti-epidemic support for mass events with international participation, MR 3.1.0079 / 2-13, p. 12 (2020).

12. V. Loskutova, Digital Science, 5 (5) (2020). 